\title{
IMPLEMENTASI STRATEGI DALAM PENANGANAN PEMBIAYAAN MURABAHAH BERMASALAH PADA KSPPS AL-MUBAROK SIDOARJO
}

\author{
Dinda Kartika ${ }^{1}$ \& Renny Oktafia ${ }^{2}$ \\ ${ }^{1 \& 2}$ Program Studi Perbankan Syariah, Pascasarjana Universitas Muhammadiyah Sidoarjo \\ Email: kartikadinda8@gmail.com,renny.oktafia@umsida.ac.id
}

\begin{abstract}
ABSTRAK
Penelitian ini bertujuan untuk mengetahui implementasi strategi yang dilakukan KSPPS Al-Mubarok dalam menangani pembiayaan murabahah bermasalah akibat penurunan pertumbuhan ekonomi nasional yang disebabkan oleh pandemi covid-19. Keadaan ekonomi Indonesia yang menurun pada triwulan pertama tahun 2020 sebesar 2,97\% merupakan faktor eksternal yang menyebabkan pembiayaan dapat bermasalah. Penghasilan para pelaku UMKM di Indonesia yang menurun membuat kegiatan pembiayaan disuatu lembaga sosial yang membiayainya ikut terganggu, karna umumnya UMKM mendapatkan pinjaman dana usaha dari lembaga keuangan mikro seperti koperasi syariah melalui beberapa jenis pembiayaan seperti murabahah, mudharabah, dan musyarakah. Hasil penelitian menunjukkan bahwa strategi yang dilakukan KSPPS Al-Mubarok terbukti mampu mengatasi permasalahan pembiayaan murabahah yang terjadi dan berdampak baik terhadap tanggung jawab nasabah dalam memenuhi kewajibannya. Peneliti menggunakan metode pendekatan studi kasus untuk bisa mengamati sepenuhnya permasalahan yang terjadi dan pemecahan masalah (problem solved) yang dilakukan oleh koperasi.
\end{abstract}

Kata Kunci : Murabahah, Pembiyaan Bermasalah, UMKM, KSSPS Al-Mubarok.

\begin{abstract}
This study aims to find out the implementation of the strategy carried out by KSPPS Al - Mubarok in handling problematic murbahah financing due to the decline in national economic growth caused by the covid-19 pandemic. Indonesia's economic downturn in the first quarter of 2020 of $2.97 \%$ is an external factor that causes financing to be problematic. The declining income of UMKM in Indonesia makes financing activities in a social institution that finances it disrupted, because generally UMKM get business loans from microfinance institutions such as sharia cooperatives through several types of financing such as murabahah, mudharabah, and musyarakah. The results showed that the strategy conducted by KSPPS Al - Mubarok proved able to overcome the problems of murabahah financing that occurred and have a good impact on the customer's responsibility in fulfilling their obligations. Researchers use case study approach method to be able to fully observe the problems that occur and problem solved conducted by cooperatives.
\end{abstract}

Keywords : Murabahah, Problematic Financing, UMKM, KSPPS Al-Mubarok. 


\section{PENDAHULUAN}

Lembaga keuangan melakukan pembangunan ekonomi berkesinambungan guna meratakan pendapatan dan mensejahterakan rakyat, melalui pemberian dana maupun fasilitas. Contohnya seperti pemberian modal usaha baik berupa dana atau barang kepada pelaku ekonomi untuk memperbesar, mengembangkan, dan mempertahankan usahanya. Sehingga secara langsung atau tidak langsung hal tersebut dapat membuat pendapatan masyarakat merata dan mengurangi angka pengangguran.

Pada tahun 2019 akhir, Indonesia dilanda pandemi covid-19 yang membuat perekonomian nasional melemah. Para pelaku ekonomi mengalami penurunan penghasilan sejak diberlakukannya pembatasan sosial berskala besar (PSBB) oleh pemerintah pada tanggal 14 April 2020 guna mencegah tersebarnya virus covid-19. Badan Pusat Statistik (BPS) mencatat ada 64,2 juta usaha mikro kecil di Indonesia, itu berarti sebesar $99,9 \%$ usaha yang beroperasi di Indonesia di dominasi oleh usaha mikro kecil. Otomatis dampak paling besar perekonomian turun akibat pandemi ada pada bidang usaha mikro kecil, karena UMKM memegang porsi paling besar dalam skala bisnis di Indonesia (Oktafia, 2017).

Kelompok usaha mikro kecil termasuk dalam sektor usaha riil dengan kepemilikan modal yang terbatas. Salah satu kendala umum yang dialami pengusaha mikro adalah susahnya mendapat akses permodalan dari perusahaan perbankan, maka dari itu diperlukan lembaga keuangan mikro (non bank) yang dapat menjangkau seluruh lapisan masyarakat (Ridwan, 2004). Karena lembaga keuangan mikro mempunyai persyaratan yang lebih mudah jika dibandingkan dengan perbankan, jadi usaha mikro bisa dengan mudah mengajukan permohonan guna mendukung permodalan nya (Oktafia, 2017). Berdasarkan prinsipnya, lembaga keuangan mikro tersebut terbagi dalam 2 jenis, yaitu lembaga keuangan mikro dengan sistem konvensional dan sistem syariah (Ayusafitri et al., 2015).

Salah satu lembaga keuangan mikro yang dapat menjangkau seluruh lapisan masyarakat adalah koperasi syariah. Koperasi syariah merupakan lembaga mikro syariah yang kredibel menangani permasalahan ekonomi masyarakat kecil. Sistem koperasi syariah muncul di Indonesia pada tahun 1992, ketika BMT Bina Insan Kamil pertama kali didirikan di Jakarta (Lita dan Oktafia, 2020). Tapi keberadaan koperasi syariah mulai dilirik pada tahun 2000an saat dimana dunia perbankan syariah di tanah air mulai berkembang akibat terjadinya krisis moneter tahun 1997. Sistem syariah ini diadopsi dari sistem-sistem perbankan dunia arab terutama dari negara Pakistan yang menjadi pelopor perbankan syariah yang sukses secara global (Primasatya, 2014).

Koperasi syariah yang biasa dikenal oleh masyarakat dengan sebutan KJKS (Koperasi Jasa Keuangan Syariah), UJKS (Unit Jasa Keuangan Syariah), atau KSPPS (Koperasi Simpan Pinjam dan Pembiayaan Syariah) telah berkembang dan menjadi tempat bagi masyarakat muslim yang membutuhkan pengelolaan sistem ekonomi berbasis syariah (Sofiani, 2014).

Pada 31 desember 2019, Kementrian Koperasi dan UKM mencatat jumlah Koperasi Simpan Pinjam dan Pembiayaan Syariah (KSPPS) yang tersebar di Indonesia sebanyak 4.046 unit. Ini berarti KSPPS memegang porsi sebesar 3,29\% dari total keseluruhan Koperasi di Indonesia yang berjumlah 123.048 unit.

Koperasi syariah berlandaskan pada surat Al-Maidah ayat 2, dimana terdapat unsur tolong menolong (ta'awun) dan kerja sama (syirkah) menganjurkan saling tolong menolong untuk kebaikan, dan melarang tolong menolong yang menimbulkan dosa. KSPPS memiliki kegiatan usaha berupa simpanan, pinjaman, serta pembiayaan. Termasuk pembiayaan untuk usaha mikro kecil dalam sektor perikanan, perkebunan, 
perairan, pertanian, perdagangan, dan masih banyak lagi sesuai ketentuan yang telah ditetapkan oleh masing-masing koperasi serta menerima penyaluran dana melalui zakat, infaq, dan sedekah. Dalam operasionalnya, koperasi syariah dikenal memiliki 3 model pembiayaan sesuai dengan konsep pembiayaan dalam ekonomi Islam, yaitu mudharabah, musyarakah, dan murabahah (Lubis dan Agusti, 2019).

Dari uraian tersebut bisa disimpulkan peran koperasi syariah sangat berpengaruh dalam membantu berlangsungnya usaha mikro kecil. Ini membuat koperasi syariah juga terkena dampaknya dari pandemi covid-19, karena koperasi dan usaha mikro kecil saling berhubungan satu sama lain. Itu artinya jika usaha mikro mengalami masalah ekonomi akan berdampak pada kelancaran pembiayaan di koperasi syariah, begitupun sebaliknya. Koperasi syariah menggunakan mekanisme pembiayaan dengan sistem bagi hasil (no riba) sesuai dengan prinsip syariah. Jika usaha nasabah tidak berjalan dengan lancar maka pembagian ijarah dan pembayaran cicilan dengan koperasi syariah tidak dapat dilaksanakan dengan baik sebagaimana mestinya yang telah diperjanjikan.

Hal tersebut yang terjadi pada KSPPS Al-Mubarok Sidoarjo. Tutur ibu Dwi Setyowati, SE sebagai Kasie Operasional dan Umum di KSPPS AlMubarok, pembiayaan murabahah bermasalah lebih sering disebabkan oleh faktor eskternal terutama di masa pandemi covid-19 ini. Nasabah yang susah untuk mempertahankan usahanya di masa pandemi karna kecukupan modal yang tidak memadahi serta pendapatan yang berkurang, akhirnya membuat pembiayaan murabahah dalam KSPPS Al-Mubarok pun ikut terganggu. Namun KSPPS Al-Mubarok telah memiliki strategi penanganan dalam upaya menyelesaikan pembiayaan murabahah bermasalah.

\section{TINJAUAN PUSTAKA}

\section{Koperasi Simpan Pinjam dan Pembiayaan Syariah (KSPPS)}

Koperasi simpan pinjam dan pembiayaan syariah atau biasa disingkat KSPPS yang sebelumnya bernama KJKS (Koperasi Jasa Keuangan Syariah) (Mardani, 2015). Merupakan lembaga keuangann mikro syariah khas Indonesia yang unik karena KSPPS menjalankan peran ganda sebagai lembaga tamwil (bisnis) dan sebagai penghimpun, pengelola, dan penyalur dana zakat, infaq, shadaqah, dan wakaf (ZISWAF). Sebagian besar KSPPS memilih menyalurkan dan memanfaatkan dananya untuk pemberdayaan, terutama untuk pelaku usaha mikro kecil.

KSPPS memang memiliki peran yang sama dengan BMT (Baitul Maal wat Tamwil) karena terlahir dari BMT. Dalam operasionalnya umumnya KSPPS memiliki produk simpanan (funding) yang terdiri dari tabungan wadiah dan tabungan mudharabah. Dan produk pembiayaan (financing) terdiri dari pembiayaan murabahah, pembiayaan musyarakah, dan pembiayaan mudharabah.

Dasar hukum dalam berdirinya KSPPS ditandai dengan ada dan berlakunya Undang-Undang Nomor 23 Tahun 2014. Dan pada tahun 2015 pemerintah bidang perkoperasian menerbitkan Permenkop dan UKM dengan Nomor 16/2015 mengenai Usaha Simpan Pinjam dan Pembiayaan Syariah yang dilakukan koperasi, lalu menerbitkan Keputusan Menteri Koperasi dan UKM dengan Nomor 91/2004 yang berisi tentang ditunjuknya koperasi untuk melaksanakan Kegiatan Usaha Jasa Keuangan Syariah. Sehingga terjadilah sebuah perubahan yang tadinya disebut KJKS/UJKS menjadi KSPPS/USPPS.

Tujuan utama KSPPS berdasarkan Undang-Undang Nomor 25 Tahun 1992 pasal 3 yang berbunyi ; "koperasi bertujuan memajukan kesejahteraan anggota pada khususnya dan masyarakat pada umumnya serta ikut membangun tatanan perekonomian 
nasional dalam rangka mewujudkan mensejahterakan masyarakat yang maju, adil, dan makmur berdasarkan pancasila dan UUD 1945". Sedangkan Fungsi KSPPS adalah :

1) Memaksimalkan serta mengembangkan potensi anggotanya dan mayarakat guna mencapai kesejahteraan ekonomi.

2) Memperkuat kualitas SDI (sumber daya insani) para anggotanya termasuk nasabah, untuk berlaku jujur (amanah), proffesional (fathonnah), dan konsekuen (istiqomah) berdasarkan prinsip ekonomi Islam (Wardhani, 2013).

3) Ikut andil dalam mengembangkan perekonomian mikro nasional.

4) Membantu menumbuhkan usaha - usaha milik anggota nya (Sofiani, 2014).

\section{Pembiayaan Murabahah}

Murabahah didefinisikan sebagai suatu akad penjualan barang sesuai harga pokok (cost) yang kemudian ditambah margin atau keuntungan sesuai yang disepakati antara penjual dan pembeli. Karakteristik murabahah yaitu penjual harus memberitahukan kepada pembeli jumlah harga pembelian produk dan keuntungan yang ditetapkan pada harga pokok (cost) (Wiroso, 2005).

Murabahah merupakan produk penyaluran dana yang sering digunakan Koperasi syariah dalam memberikan pembiayaan kepada nasabahnya dan kerap kali digemari. Alasannya karena akad murabahah memiliki karakter yang profitable, mudah diterapkan, dan risk factor yang ringan diperhitungkan (Inayah, 2009).

Ahli hukum Islam Wahbah AzZuhaili menyatakan beberapa syarat dalam jual beli murabahah (bai' al-murabahah), yaitu : Pertama, pembeli harus mengetahui harga pokok dari barang yang akan dibelinya, karna itu adalah syarat sah bai' al-murabahah. Kedua, pembeli juga harus mengetahui harga margin (keuntungan) yang dipatok penjual, karena margin merupakan bagian dari harga. Disini diwajibkan adanya transparansi.

Penulis menyimpulkan, pada koperasi syariah murabahah adalah pembiayaan usaha dalam bentuk jual beli dimana pihak koperasi syariah sebagai penjual transparan (memberitahu) kepada nasabah sebagai pembeli terkait harga pokok barang tersebut, dan nasabah (pembeli) membelinya berdasarkan harga pokok serta memberi margin (keuntungan) kepada pihak koperasi (penjual) sesuai yang telah disepakati bersama.

Dalam Islam, murabahah merupakan jual beli yang tidak semerta-merta hanya untuk mencari untung tapi sebagai sarana tolong-menolong sesama umat muslim (Ependi and Thamrin, 2021). Salah satu ayat Al-Qur'an yang memperbolehkan terjadinya jual beli (murabahah) adalah firman Allah dalam surat Al-Baqarah ayat 275 :
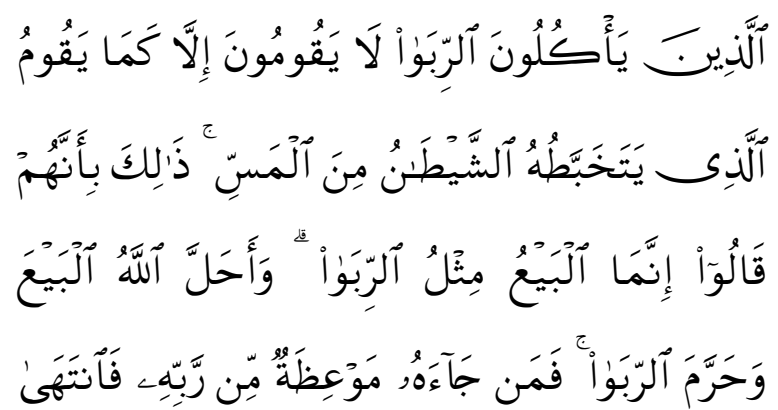

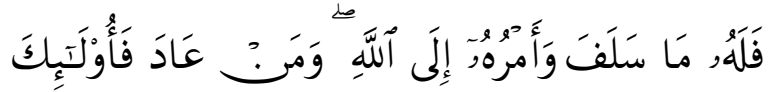

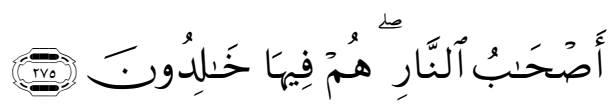

Artinya : orang-orang yang Makan (mengambil) riba tidak dapat berdiri melainkan seperti berdirinya orang yang kemasukan syaitan lantaran (tekanan) penyakit gila. Keadaan mereka yang demikian itu, adalah disebabkan mereka berkata (berpendapat), Sesungguhnya jual beli itu sama dengan riba, Padahal Allah telah menghalalkan jual beli dan mengharamkan riba. orang-orang yang telah sampai kepadanya larangan dari Tuhannya, lalu terus berhenti (dari mengambil riba), Maka baginya apa yang telah diambilnya dahulu (sebelum datang 
larangan); dan urusannya (terserah) kepada Allah. orang yang kembali (mengambil riba), Maka orang itu adalah penghunipenghuni neraka; mereka kekal di dalamnya. (Q.S. Al-Baqarah ayat 275)

\section{Pembiayaan Bermasalah}

Singkatnya pembiayaan (financing) adalah sebuah pendanaan yang dikeluarkan lembaga keuangan guna mendukung sebuah usaha atau investasi nasabahnya (Muhammad, 2005). Sedangkan pembiayaan bermasalah adalah penyaluran dana yang dalam pelaksanaannya terjadi hal-hal tidak diinginkan, seperti pembiayaan tidak lancar, debitur tidak memenuhi syarat-syarat yang telah dijanjikan, dan pembiayaan yang angsurannya tidak tepat waktu.

Jadi, pembiayaan bermasalah merupakan sebuah resiko dalam suatu kegiatan pembiayaan, karena pastinya memberikan dampak negatif untuk kedua belah pihak (Karim, 2010). Robert Tampubolon mengatakan bahwa "resiko kredit adalah eksposur yang timbul sebagai akibat kegagalan pihak lawan (counterparty) memenuhi kewajibannya" (Tampubolon, 2004). Sehingga dalam menghadapi pembiayaan bermasalah yang jadi perhatian lembaga keuangan adalah karakter nasabah.

Terdapat beberapa faktor yang menyebabkan terjadinya pembiayaan bermasalah, diantaranya;

Faktor Internal yang meliputi :

(a) Kurang memamahami bisnis yang dijalankan nasabah.

(b) Kurangnya melakukan evaluasi terkait keuangan nasabah.

(c) Kesalahan dalam mengatur fasilitas pembiayaan kepada nasabah (sehingga terjadi sidestreaming) (Usanti \& Shomad, 2008).

(d) Lemahnya monitoring dan supervisi, dan lainnya.

meliputi: a) Nasabah yang tidak amanah (jujur).

b) Nasabah kurang dalam mengelola usaha, sehingga kalah dalam persaingan dagang.

c) Usaha yang dimiliki nasabah masih baru, belum banyak pengalaman dan rentan terjadi kerugian jika nasabah tidak memiliki strategi.

d) Berkurangnya pendapatan usaha nasabah akibat kejadian-kejadian tak terduga lainnya seperti bencana alam atau pandemi.

\section{Definisi Strategi}

Dalam KBBI (Kamus Besar Bahasa Indonesia) tahun 2007, terdapat poin yang tertulis bahwa strategi adalah rencana yang cermat mengenai kegiatan untuk mencapai sasaran khusus. Strategi merupakan suatu rencana yang disusun guna mencapai suatu tujuan dan target tertentu.

Glueck dan Jauch (2000) mengatakan bahwa rencana terpadu yang disusun dan disatukan secara menyeluruh untuk menghadapi tantangan lingkungan guna memastikan tujuan perusahaan dapat tercapai disebut strategi.

Menurut Mintzberg' (1979) strategi adalah respon yang diberikan perusahaan atau organisasi dalam menghadapi ancaman internal maupun eksternal yang dapat mempengaruhi berjalannya suatu perusahaan atau organisasi.

Dapat disimpulkan bahwa strategi merupakan sebuah susunan rencana yang dipersiapkan oleh suatu perusahaan maupun organisasi untuk menghadapi permasalahan yang mereka hadapi baik dari sisi internal maupun eksternal, agar perusahaan bisa berjalan kembali sebagai mana mestinya dan mencapai tujuan yang di inginkan.

\section{METODE PENELITIAN}

Penelitian ini menggunakan metode penelitian kualitatif. Metode kualitatif dipilih karena dianggap sesuai dengan permasalahan yang sedang di teliti yakni permasalahan pembiayaan murabahah yang 
dialami KSPPS Al-Mubarok, dimana menganalisis fenomena pada suatu tempat lalu memahami serta menganalisis permasalahan tersebut. Permasalahan didalam penelitian kualitatif bersifat tidak pasti dan masih terus berkembang seiring berjalannya waktu (Sugiyono, 2018), sedangkan jenis pendekatan yang digunakan adalah pendekatan studi kasus yang bertujuan untuk mendalami secara detail bagaimana interaksi lingkungan sosial, individu, organisasi, lembaga, dan lain - lain terkait dengan permasalahan yang terjadi di tempat penelitian (Primasatya, 2014).

Lokasi penelitian dilakukan di kantor pusat KSPPS Al-Mubarok yang terletak di Jl. Keramean Sumorame Candi Sidoarjo dan kantor cabangnya yang terletak di Karangbong Gedangan Sidoarjo. Waktu penelitian dilakukan pada tanggal 12 Desember 2020 sampai dengan 03 Maret 2021. Metode pengumpulan data yang digunakan peneliti adalah :

\section{Obervasi}

Dalam penelitian ini, peneliti menggunakan teknik observasi partisipasi pasif (Sugiyono, 2018).

2. Wawancara

Teknik wawancara yang digunakan secara terstruktur untuk menggali informasi dalam mendapatkan data primer.

\section{Dokumentasi}

Data penelitian diperoleh dari rekaman hasil wawancara, foto, chat via whatsapp dengan pengurus koperasi, dan data Laporan Rapat Akhir Tahunan KSPPS Al-Mubarok.

\section{HASIL DANPEMBAHASAN}

\section{Prosedur Pembiayaan Murabahah Pada KSPPS Al -Mubarok.}

Koperasi simpan pinjam dan pembiayaan syariah yang berdiri pada November 2011 dan mempunyai nomor badan hukum: telah berkembang, dan hingga tahun 2020 telah memiliki total 10.350 nasabah. KSPPS Al-Mubarok memiliki 2 produk pembiayaan, yakni murabahah dan musyarakah untuk memenuhi kebutuhan pembiayaan nasabahnya. Namun jenis pembiayaan yang paling diminati nasabah adalah pembiayaan murabahah, karena lebih efisien dan dinilai lebih sesuai untuk kebutuhan usaha mereka.

Dalam pembiayaan murabahah di KSPPS Al-Mubarok, koperasi berperan sebagai penjual dan nasabah sebagai pembeli. Ada 2 mekanisme pembiayaan murabahah yang ada dalam KSPPS AlMubarok, yang pertama adalah pemberian barang (pihak koperasi membeli barang usaha yang diperlukan nasabah) lalu nasabah membayar dengan cara mengangsur setiap bulan beserta nisbah yang telah disepakati, dan yang kedua adalah pemberian modal (uang) kepada nasabah untuk membeli barang (keperluan usaha) yang diinginkan dengan pembayaran angsuran setiap bulan juga beserta nisbah yang telah disepakati. (Hasil wawancara dengan Ibu Sustianik selaku Kepala Divisi Operasional)

Nasabah yang mengajukan pembiayaan murabahah pada KSPPS AlMubarok harus memenuhi persyaratan yang ditetapkan koperasi. KSPPS Al-Mubarok akan melakukan checking laporan penilaian keuangan nasabah dengan pengisian form yang akan dilakukan oleh nasabah, lalu melakukan survey usaha nasabah dengan mengunjungi lokasi usaha nasabah yang akan dibiayai secara langsung, serta menggunakan penilaian feeling dan insting melalui komunikasi antara Account Officer dan nasabah. Dengan penilaian feeling dan insting pihak koperasi akan mengetahui watak serta karakter nasabah. Sehingga koperasi bisa menentukan apakah nasabah tersebut layak mendapatkan pembiayaan atau tidak. (Hasil wawancara dengan Bapak M. Yusuf Harianto selaku Account Officer)

Koperasi juga tidak luput dengan analisis 5C kepada nasabah yang meliputi; 
Character, Capacity, Capital, Collateral, Condition. Adapun persyaratan pembiayaan lainnya yang harus dilengkapi nasabah adalah; 1) Fotokopi KTP diri dan suami/istri masing -masing 3 lembar, 2) Fotokopi KSK 2 lembar, 3) Slip gaji terakhir, 4) Fotokopi surat nikah 2 lembar, 5) Jaminan BPKB, ATM, Buku tabungan dan Jamsostek.

Apabila nasabah telah memenuhi semua kriteria, maka pelaksanaan pembiayaan murabahah akan berlanjut pada tanda tangan perjanjian antara pihak koperasi dan nasabah. Selama pembiayaan murabahah berlangsung, pihak koperasi akan selalu mengawasi usaha yang dijalankan oleh nasabah. Hal ini dilakukan untuk langkah awal dalam mendampingi usaha nasabah, sehingga jika terjadi indikasi pembiayaan bermasalah di awal angsuran koperasi dapat memikirkan langkah-langkah untuk mengatasinya. Laporan keuangan usaha nasabah juga tidak luput dari pengawasan koperasi. Pihak koperasi juga membangun komunikasi yang baik dan rutin dengan nasabah, untuk mencegah adanya nasabah yang kabur atau menghilang sebelum melunasi angsurannya, dan dengan begitu koperasi akan mengetahui apa saja hambatan yang dialami nasabah. Nasabah akan cenderung terbuka dengan koperasi apabila pihak koperasi menunjukkan sifat simpatik. Pada dasarnya pihak koperasi akan membangun kedekatan hubungan dengan nasabah untuk mencegah terjadinya pembiayaan murabahah bermasalah dan segera mencari solusi apabila ada hal-hal yang tidak diinginkan.

Dalam pembiayaan murabahah pada KSPPS Al-Mubarok ada kalanya nasabah tidak dapat memenuhi kewajiban membayar angsuran secara lancar dan berpotensi merugikan bagi koperasi. Khususnya dimasa pandemi covid 19 ini, pembiayaan murabahah bermasalah pada KSPPS AlMubarok mengalami peningkatan pada tahun 2020 sebesar 2\% dari tahun 2019 yang hanya sebesar $1 \%$ dari total keseluruhan jumlah pembiayaan murabahah. Meski demikian KPSS Al-Mubarok masih tergolong koperasi yang sehat, karena jumlah pembiayaan murabahah yang bermasalah relatif rendah apabila dibandingkan dengan pembiayaan murabahah yang lancar (Hasil wawancara dengan Ibu Sustianik selaku Kepala Divisi Operasional).

\section{Implementasi Strategi Dalam Penanganan Pembiayaan Murabahah Bermasalah Pada KSPPS Al-Mubarok.}

Jumlah nasabah disebuah lembaga keuangan berpengaruh terhadap besarnya resiko pembiayaan, semakin banyak jumlah anggota (nasabah) maka akan semakin besar peluang terjadinya pembiayaan bermasalah yang disebabkan oleh faktor internal maupun eksternal. Faktor internal bisa meliputi ; 1) Kesalahan atau kelalaian petugas koperasi, 2) Kurangnya analisa yang dilakukan pihak koperasi, 3) Kurangnya pengecekan saat awal proses pembiayaan, 4) Kurangnya pengalaman petugas koperasi, 5) Petugas koperasi terlalu agresif. Dan faktor eksternal meliputi ; 1) Nasabah tidak kompeten, 2) Tidak bersifat amanah, 3) Kondisi ekonomi, 4) Bencana alam, 5) Kondisi politik, dan lain-lain. Dengan jumlah nasabah mencapai lebih dari 10.000 membuat KSPPS Al-Mubarok tidak luput dari pembiayaan murabahah bermasalah meskipun kecil (Hasil wawancara dengan bapak Edy Wahono selaku Account Officer).

Pada umumnya, koperasi akan berupaya untuk mengurangi terjadinya pembiayaan murabahah bermasalah dengan memberi syarat adanya jaminan berupa sertifikat tanah maupun BPKB yang harus diberikan nasabah diawal akad. Dengan adanya barang jaminan ini, diharapkan nasabah tidak akan melupakan tanggung jawabnya, namun barang jaminan tidak akan sampai dilelang atau dijual oleh koperasi. KSPPS Al-Mubarok masih mengedepankan rasa kemanusiaan, barang jaminan ini bukanlah milik koperasi dan akan tetap dikembalikan apabila nasabah sudah tidak memiliki apa-apa untuk melunasi hutanghutangnya. 
Langkah awal yang dilakukan KSPPS Al-Mubarok apabila terjadi pembiayaan murabahah bermasalah adalah melakukan pendekatan secara kekeluargaan dan moral, dengan cara menghubungi nasabah yang pembayarannya bermasalah lalu menanyakan apa hambatan atau masalah yang dialami. Koperasi akan memberi peringatan lalu melakukan musyawarah dengan nasabah yang bersangkutan untuk mencari solusinya dan memberikan tenggang waktu lebih untuk nasabah melunasi angsuran (Hasil wawancara dengan Bapak Sarpandi selaku pembina/penasehat usaha). Namun apabila strategi tersebut tidak berjalan baik karena nasabah tetap tidak sanggup membayar, maka koperasi akan melakukan Rescheduling dan Reconditioning.

Langkah selanjutnya Rescheduling dan Reconditioning yang merupakan tugas Account Officer, ini dilakukan apabila nasabah dirasa masih sanggup membayar serta memiliki rasa tanggung jawab (Shobirin) dengan kewajibannya. Jika pembiayaan tersebut masih memiliki harapan untuk berjalan normal kembali, pihak koperasi akan memberi keringanan kepada nasabah seperti menjadwalkan waktu angsuran kembali (rescheduling). Namun apabila nasabah tidak memiliki rasa tanggung jawabdan kemampuan membayar sama sekali maka pihak koperasi akan menyarankan penjualan objek transaksi (barang yang diperjual belikan dalam akad murabahah). Hasil penjualan itulah yang nantinya digunakan untuk melunasi hutang nasabah.

Dimasa pandemi covid-19 ini pembiayaan murabahah bermasalah umumnya dikarenakan kondisi keuangan dan usaha nasabah yang menurun. Strategi yang dilakukan KSPPS Al-Mubarok pada kondisi ini yaitu :
1. Melakukan Revitalisasi dengan cara:

a. Restructuring (Penataan kembali)

Pihak KSPPS Al-Mubarok akan melakukan penataan kembali yang meliputi:

1) Suplesi (Penambahan dana)

Ini bisa dilakukan apabila nasabah selalu membayar angsuran tepat waktu setiap bulannya. Maka apabila kondisi keuangan atau usaha nasabah tiba-tiba down, pihak koperasi bisa memberikan suplesi serta penambahan jangka waktu pembayaran. Sisa saldo pokok pinjaman bisa diambil mitra selama jangka waktu pembiayaan sesuai dengan akad.

2) Novasi (Pembaruan hutang)

Nasabah yang tidak sanggup untuk memenuhi kewajibannya dapat mengalihkan hutangnya kepada debitur baru. KSPPS Al-Mubarok memperkenankan saudara, keluarga (terutama anak), kerabat dan rekan kerja nasabah untuk menjadi debitur baru menggantikan nasabah yang kesusahan. Dalam kasus ini nasabah telah terbebas dari kewajibannya, dan angsurannya dipindah tangankan kepada debitur yang baru melalui janji tertulis.

b. Rescheduling (Penjadwalan kembali)

KSPPS Al-Mubarok akan melakukan penjadwalan kembali terkait jangka waktu pembayaran, jadwal pembayaran dan jumlah angsuran apabila kemampuan nasabah dalam membayar yang sekarang tidak sesuai seperti pada perjanjian awal pembiayaan. Termasuk nasabah yang penghasilan usahanya menurun akibat pandemi covid-19 ini, pihak koperasi akan merubah jadwal pembayaran. Misalnya jika ditargetkan angsuran nasabah selesai dalam 6 bulan, maka koperasi dapat memperpanjang jangka waktu pembayaran menjadi 12 bulan agar jumlah angsuran nya mengecil.

c. Reconditioning (Persyaratan kembali)

Reconditioning pembiayaan merupakan upaya yang dilakukan koperasi dalam mengatasi pembiayaan bermasalah 
melalui penataan dan persyaratan pembiayaan kembali. Reconditioning yang dilakukan KSPPS Al-Mubarok pada pembiayaan murabahah bermasalah diantaranya:

1) Memberi keringanan kepada nasabah.

Pihak koperasi memberi potongan angsuran, pelunasan dini bahkan memperpanjang waktu jatuh tempo yang untuk meringankan pembayaran angsuran nasabah (Hasil wawancara dengan bapak Edy Wahono selaku Account Officer).

2) Menjual objek transaksi.

Objek transaksi yang dimaksud adalah barang yang diperjual belikan dalam akad murabahah melalui KSPPS Al-Mubarok kepada nasabah, barang tersebut bisa dijual oleh pihak koperasi untuk melunasi sisa-sisa hutang nasabah. Objek transaksi tersebut biasanya berupa; Mesin, Peralatan masak, Komputer, Motor, Pick Up dan lain sebagainya (Hasil wawancara dengan bapak Edy Wahono selaku Account Officer).

Apabila KSPPS Al-Mubarok telah mengimplementasikan strategi diatas namun nasabah masih tidak sanggup memenuhi kewajibannya dan dirasa keluaga serta kerabat nasabah juga sudah tidak mampu lagi untuk melunasi hutang nasabah, maka pihak koperasi akan melakukan penyelesaian secara Ibra'. Yaitu menyelesaikan pembiayaan murabahah bermasalah dengan cara mengikhlaskan dan menghapus hutang nasabah. Penyelesaian secara Ibra' dilakukan dengan cara:

\section{Write Off.}

Dalam pelaksanaan write off, KSPPS Al-Mubarok menetapkan 2 jenis ketentuan atau syarat, yakni; a) Hapus Buku.

KSPPS Al-Mubarok melakukan penghapus bukuan nasabah yang memiliki permasalahan dalam pembiayaan murabahah, namun koperasi masih tetap menagih. Yang ditagih hanyalah pinjaman pokok saja (tanpa nisbah), hal ini bisa dipertimbangkan oleh KSPPS Al-Mubarok apabila nasabah sudah tidak memiliki penghasilan dari usaha yang dijalankan, serta pelaksanaan strategi revitalisasi gagal. Besarnya pokok pinjaman yang akan diangsur bisa di musyawarahkan kembali menyesuaikan dengan kemampuan membayar nasabah. Jika dalam sebulan nasabah hanya berpenghasilan $\mathrm{Rp}$. $50.000,00$ (belum dikurangi kebutuhan hidup), koperasi akan memberi keringanan dan melakukan write off sehingga nasabah hanya perlu mengangsur Rp. 10.000,00 saja setiap bulannya hingga jumlah pinjaman pokok habis.

b) Hapus Tagih.

Ini adalah langkah terakhir yang dilakukan, yaitu melakukan penghapus bukuan dan tagihan pembiayaan bermasalah. Nasabah yang bersangkutan sudah tidak perlu lagi melakukan angsuran setiap bulan. Nasabah juga sudah tercatat tidak memiliki hutang lagi di KSPPS Al-Mubarok.

\section{Dampak Strategi Penanganan Pembiayaan Murabahah Bermasalah pada KSPPS Al-Mubarok.}

Dari strategi yang telah diterapkan KSPPS Al-Mubarok dalam menangani permasalahan pembiayaan murabahah, ternyata terdapat dampak yang cukup signifikan. Terbukti dalam laporan Rencana Anggaran Pendapatan dan Belanja (RAPB) KSPPS Al-Mubarok Tahun Buku 20152020. 
2021, Jurnal Tabarru' : Islamic Banking and Finance 4 (1) : 127 - 138

Tabel 1. Jumlah Piutang dan Margin Murabahah pada KSPPS Al-Mubarok.

\begin{tabular}{cccc}
\hline No. & Tahun & Jumlah \\
\hline & & Piutang Murabahah & Margin Murabahah \\
\hline 1. & 2015 & Rp. 4.288.415.800 & Rp. 812.678.900 \\
\hline 2. & 2016 & Rp. 5.442.678.300 & Rp. 1.360.358.150 \\
\hline 3. & 2017 & Rp. 6.102.002.392 & Rp. 1.908.003.250 \\
\hline 4. & 2018 & Rp. 7.810.691.750 & Rp. 2.507.420.009 \\
\hline 5. & 2019 & Rp. 7.056.034.250 & Rp. 2.903.842.450 \\
\hline 6. & 2020 & Rp. 7.943.648.07 & Rp. 3.426.534.091 \\
\hline
\end{tabular}

Sumber: laporan Rencana Anggaran Pendapatan dan Belanja (RAPB) KSPPS Al-Mubarok Tahun Buku 2015-2021

Dalam laporan Rencana Anggaran Pendapatan dan Belanja (RAPB) KSPPS Al-Mubarok pada tahun ke tahun margin murabahah terus mengalami peningkatan. Hal ini berarti pembiayaan murabahah bermasalah yang terjadi tidak membuat margin murabahah yang diperoleh koperasi menurun. Adapun dampak yang lainnya dari strategi yang dilakukan, yakni; 1) Strategi Revitalisasi yang telah di implementasikan oleh koperasi sangat berpengaruh terhadap tanggung jawab nasabah dalam memenuhi kewajibannya. Lewat strategi pendekatan kekeluargaan dan moral serta penjadwalan kembali yang dilakukan Account Officer KSPPS Al-Mubarok mampu mencegah indikasi terjadinya pembiayaan murabahah bermasalah dan menangani permasalahan pada pembiayaan (Hasil wawancara dengan bapak Edy Wahono selaku Account Officer). Dampak berikutnya, 2) Strategi yang dilakukan KSPPS AlMubarok berdampak baik terhadap perolehan margin murabahah pada tahun 2020. Padahal, pembiayaan murabahah bermasalah di KSPPS Al-Mubarok mengalami peningkatan sebesar $2 \%$ pada tahun yang sama. Koperasi mampu mengimplementasi kan strategi Restructuring, Rescheduling, Reconditioning dengan cukup baik sehingga realisasi (rencana) margin murabahah di tahun 2020 sebesar Rp.
3.290.900.100 terlampaui hingga $\mathrm{Rp}$. 3.426.534.091.

\section{KESIMPULAN}

Berdasarkan dari penelitian yang telah dilakukan serta hasil yang telah dipaparkan pada bab sebelumnya, peneliti menarik beberapa kesimpulan, yakni; 1) KSPPS Al-Mubarok melakukan strategi penyelesaian pada pembiayaan murabahah bermasalah sesuai dengan Standar Operasional Prosedur Koperasi Jasa Keuangan (KJKS) dan Unit Jasa Keuangan Syariah (UJKAS), yaitu melakukan 3R; Restructuring, Rescheduling, Reconditioning. 2) Strategi 3R yang telah dilakukan oleh koperasi berdampak baik terhadap tanggung jawab nasabah dalam memenuhi kewajiban, dengan cara pendekatan kekeluargaan, moral serta penjadwalan kembali oleh Account Officer mampu membuat nasabah merasa lebih dipahami dan dimengerti kesulitannya sehingga nasabah berusaha tetap bertanggung jawab terhadap hutanghutangnya. 3) Langkah terakhir yang dilakukan koperasi apabila strategi yang telah dilakukan diatas tidak berhasil adalah melakukan penyelesaian secara Ibra', yang dilakukan dengan cara Write Off terhadap pembiayaan dan hutang nasabah yang bermasalah. Sehingga nasabah tidak lagi harus memenuhi kewajiban angsurannya. 4) KSPPS AlMubarok tidak mengambil langkah akhir 
dengan mengeksekusi barang jaminan nasabah, dikarenakan masih mengedepankan rasa kemanusiaan. 5) Strategi yang dilakukan KSPPS AlMubarok terbukti mampu dalam mengatasi permasalahan pembiayaan murabahah, terbukti dengan margin murabahah yang diperoleh koperasi setiap tahun ke tahun tidak pernah mengalami penurunan yang signifikan, bahkan pada tahun 2020 (pada masa pandemi) margin murabahah melampaui realisasi yang telah ditetapkan.

\section{DAFTAR PUSTAKA}

Ayusafitri, D., Aminah, \& Irawati. 2020. Penyelesaian Pembiayaan Akad Musyarakah Bermasalah Pada Koperasi BMT Syari'ah Makmur Bandar Lampung. Notarius Jurnal Studi Kenotariatan, 13(1), p. 236249.

Ependi, R, \& Thamrin, H. 2021. Pembiayaan Murabahah di PT. Federal International Finance Syariah Pekanbaru. Jurnal Tabarru' : Islamic Banking and Finance, 4(1), p. 26-36.

Glueck, W, F \& Jauch, L, R. 1994 Manajemen Strategis dan Kebijakan Perusahaan. Erlangga. Jakarta.

Inayah, N. 2009. Strategi Penanganan Pembiayaan Bermasalah Pada Pembiayaan Murabahah di BMT Bina Ihsanul Fikri Yogyakarta. Skripsi thesis, UIN Sunan Kalijaga Yogyakarta.

Karim, A. A. 2010. Bank Islam Analisis Fiqih dan Keuangan. PT Raja Grafindo Persada. Jakarta.

Lita, A, \& Oktafia, R. 2020 Strategi Optimalisasi Penghimpunan Dana Nasabah Bagi Perkuatan Permodalan di BMT Mawaddah Kantor Cabang Pandaan Pasuruan. Al-Mustashfa: Jurnal Penelitian
Hukum Ekonomi Islam, 5(2), p. 171182.

Lubis, M. Z., \& Agusti, N. (2019). Sumber Daya Manusia Koperasi Jasa Keuangan Syariah (KJKS) Di Kota Padang: Dilema Antara Pengelolaan Dan Pemahaman Konsep. Jurnal Ilmiah Syiar, 19(01), p. 77-89.

Mardani. 2015. Aspek Hukum Lembaga Keuangan Syariah di Indonesia. Kencana. Jakarta.

Mintzberg', H. 1979. The Structuring of Organizations. Prentice-Hall. New York.

Muhammad. 2005. Manajemen Bank Syariah. UPP AMP YKPN. Yogyakarta.

Oktafia, R. 2017. Percepatan Pertumbuhan Usaha Mikro, Kecil Dan Menengah (UMKM) Melalui Perkuatan Lembaga Keuangan Mikro Syariah (LKMS) Di Jawa Timur. Annual Conference for Muslim Scholars (AnCoMS) Kopertais Wilayah IV Surabaya, (Seri 1), p. 85-92.

Primasatya, Arya. 2014. Penanganan Pembiayaan Mudharabah Bermasalah di Koperasi Syariah Kanindo Jatim (Studi di Koperasi Syariah Kanindo Jatim, Dau, Kabupaten Malang). Jurnal Ilmiah Fakultas Hukum Universitas Brawijaya, 3.

Ridwan, M. 2004. Manajemen Baitul Maal wat Tanwil (BMT). UII Press. Yogyakarta.

Sofiani, Triana. 2014. Konstruksi Norma Hukum Koperasi Syariah Dalam Kerangka Sistem Hukum Koperasi Nasional. Jurnal Hukum Islam (JHI), 12(2), p. 135-151. 
Sugiyono, P. D. 2018. Metode Penelitian Kuantitatif, Kualitatif, dan $R \& D$. Alfabeta. Bandung.

Tampubolon, R. 2004. Risk Management: Pendekatakan Kualitatif Untuk Bank Komersial. PT Elex Media Komputindo. Jakarta.

Usanti, T. P., \& Shomad, A. 2008. Penyelesaian Pembiayaan Bermasalah Bank Syari'ah. Laporan Penelitian Fakultas Hukum Unair. Surabaya.

Wardhani, C. A. 2019. Peran Koperasi Simpan Pinjam Dan Pembiayaan Syariah (KSPPS) Dalam Pemberdayaan Ekonomi Masyarakat (Studi Pada BMT Fajar Cabang Bandar Lampung). Skripsi Fakultas Ekonomi dan Bisnis UIN Raden Intan Lampung.

Wiroso. 2005. Jual Beli Murabahah. UII Press. Yogyakarta. 